\title{
O GESTO DE INTERPRETAÇÃO NO DISCURSO DE HUMOR POLÍTICO: O CASO DE UMA CHARGE
}

\section{WASHINGTON SILVA DE FARIAS ${ }^{1}$; TELMA CRISTINA GOMES DA SILVA²}

\author{
Programa de Pós-Graduação em Linguagem e Ensino \\ Universidade Federal de Campina Grande \\ Rua Aprígio Veloso, 882 - 58429-900 - Campina Grande- PB - Brasil \\ washfarias@gmail.com ; profa.telma@gmail.com
}

\begin{abstract}
Resumo. Neste trabalho, refletimos sobre o discurso de humor político e sua constituição a partir de gestos de interpretação que envolvem a inscrição e movimentação de sujeitos e sentidos em/entre redes de filiação e memória. Como unidade de análise, elegemos uma charge eletrônica sobre a disputa eleitoral entre PT e PSDB, veiculada em 2015 no site charges.com.br, de Maurício Ricardo. A partir da análise do texto selecionado, observamos o trabalho do sujeito-autor sobre os fatos políticos, bem como sobre a rede de sentidos da memória política brasileira. $O$ artigo se inscreve no campo teórico da Análise de Discurso de tradição francesa e brasileira, tendo como referências básicas os trabalhos de Pêcheux e Orlandi.
\end{abstract}

Palavras-chave: Análise de Discurso; humor; política; charge.

\begin{abstract}
In this paper we reflect on the discourse of political humor and its constitution from gestures of interpretation related to inscription and movement of subjects and senses in/among affiliation and memory networks. As analysis unit, we have chosen an electronic cartoon that textualizes the electoral dispute between the political parties PT and PSDB aired in 2015 on the website charges.com.br by Maurício Ricardo. Analysis of the selected text allowed us to observe the work of subject-author signifying the political events, as well as on the network of meanings regarding Brazilian political memory. This article enrolls in the theoretical field of French and Brazilian tradition of Discourse Analysis taking as basic references Pêcheux and Orlandi's works.
\end{abstract}

Keywords: Discourse Analysis; humour; politics; cartoon.

\section{Introdução}

Comumente, entende-se o humor como um discurso ou modalidade de significação que visa provocar o riso, tendo em vista uma apreciação não convencional, não esperada da realidade. Este é, aliás, o sentido registrado no Dicionário Eletrônico

\footnotetext{
${ }^{1}$ Doutor em Linguística (UFPB). Docente na Graduação e membro do Programa de Pós-Graduação em Linguagem e Ensino (Pós-Letras) da Universidade Federal de Campina Grande (UFCG).

${ }^{2}$ Doutora em Linguística (UFPB). Pesquisadora em Estágio Pós-Doutoral no Programa de Pós-Graduação em Linguagem e Ensino da Universidade Federal de Campina Grande (UFCG).
} 
Houaiss, segundo o qual o humor é "expressão irônica e engenhosamente elaborada da realidade". De modo geral, trata-se também de um discurso crítico, que apresenta, segundo Freud (2006), uma dimensão "liberadora", de "grandeza e elevação" e de "rebeldia". Essa grandeza expressaria um "triunfo do narcisismo", enquanto a rebeldia se daria pela efetivação do "princípio do prazer", já que, pelo humor:

o ego se recusa a ser afligido pelas provocações da realidade, a permitir que seja compelido a sofrer. Insiste em que não pode ser afetado pelos traumas do mundo externo; demonstra, na verdade, que esses traumas para ele não passam de ocasiões para obter prazer. (FREUD, 2006, p. 190)

Podemos dizer, assim, que o humor não consiste apenas em provocar o riso, mas se constitui numa forma crítica de relação do sujeito com o mundo e com os sentidos, uma possibilidade de resistência do sujeito.

Ainda sobre o discurso de humor, uma referência correntemente citada é o estudo de Possenti (2002), que se ocupou da análise de piadas, considerando sobretudo sua dimensão linguística. Este estudo, segundo o autor, embora adotando um enfoque então inédito, não visava delimitar uma "linguística do humor", pois o efeito humorístico não seria da ordem da língua, mas produto de um conjunto de fatores linguísticos e não linguísticos:

a análise de textos humorísticos mostra que os aspectos explorados são os mais diversos, talvez todos, mais ou menos como são mobilizados, direta ou indiretamente, todos os recursos linguísticos para falar cotidianamente, para fazer literatura ou para a escrita em geral etc. (POSSENTI, 2002, p. 21)

A análise do humor teria, pois, relevância tanto para linguistas quanto para estudiosos do texto e do discurso, na medida em que possibilitaria a uns demonstrar fatos e princípios de certas teorias (fonológicas, morfológicas, sintáticas), a outros sustentar, por exemplo, uma concepção não formalista de língua (língua como sistema sujeito à falha, ao equívoco) ou realçar a importância das condições de produção na compreensão do funcionamento textual e discursivo da linguagem.

Considerando esta segunda direção de análise, neste trabalho investigamos o funcionamento do discurso de humor político, tomando um texto do gênero charge como unidade de observação. Pretendemos evidenciar que esse discurso tem um caráter essencialmente argumentativo, entendendo a argumentação como um processo de significação que se define tendo em vista a filiação dos sujeitos e dos sentidos a redes de memória (relação discurso/formação discursiva/interdiscurso).

Assim, pensamos o discurso de humor não apenas como um jogo de elementos linguísticos que por si só justificariam seus efeitos de sentido e ensejariam o riso, mas como um "jogo de linguagem" que, por seu acontecimento linguístico-histórico, produz e torna interpretáveis sujeitos e sentidos.

Quanto à sua dimensão política, focalizamos o humor como um espaço próprio de significação e exposição dos sentidos de poder, cujas possibilidades de leituras vão além 
daquelas que os sujeitos da política e de sua cobertura jornalística normalmente fazem. Dessa forma, essas leituras-outras, denominadas "críticas", estão ligadas à atribuição de sentidos que rompem com ou atrapalham dizeres que, no campo da política, (a)parecem (como) únicos, estáveis ou definitivos.

Nessa perspectiva, assumimos que o discurso de humor político se constitui mediante gestos de interpretação (ORLANDI, 2005, 2002, 1996), que mexem com as evidências ideológicas produtoras de certas identidades para os sujeitos e os sentidos, e fazem trabalhar o imaginário político e seus pontos de tensão discursiva.

A charge a ser analisada, denominada Ato falho, foi veiculada em julho de 2015 no site charges.com.br, instalado no portal UOL. Essa charge, que tematiza a disputa política brasileira entre PSDB e PT no período pós-eleição presidencial de 2014, foi escolhida por demonstrar de forma exemplar o funcionamento argumentativo crítico do discurso de humor.

No desenvolvimento deste trabalho, inscrito teoricamente no campo da Análise de Discurso de tradição francesa e brasileira (PÊCHEUX, 2010; PÊCHEUX \& FUCHS, 2010; ORLANDI, 2005, 2001, 1998), tecemos, de início, algumas considerações sobre como, nesse campo, são pensadas as questões da interpretação e da argumentação. Em seguida, apresentamos as condições de produção mais imediatas da charge objeto da análise e do fato político que deu origem a ela. Como esse fato diz respeito a dois atos falhos cometidos pelo político Aécio Neves, do PSDB, fazemos, na sequência, um breve apontamento sobre a noção de ato falho na perspectiva psicanalítica de Freud, sinalizando uma possibilidade de sua abordagem discursiva. Depois disso, vem a análise e interpretação discursiva propriamente dita da charge escolhida ${ }^{3}$.

\section{Os movimentos da significação: interpretação e argumentação}

Segundo Pêcheux e Fuchs (2010), a dimensão enunciativa da produção de um discurso possibilita observar os movimentos estratégicos a partir dos quais os sujeitos falam e são falados. Estes movimentos estão relacionados à questão da interpretação e de seu papel nos processos de produção e leitura de textos. A noção de interpretação, por sua vez, na perspectiva discursiva defendida por Orlandi (1996), se define por sua articulação constitutiva com o conceito de ideologia enquanto mecanismo estruturante do sujeito e do sentido:

a ideologia será então percebida como o processo de produção de um imaginário, isto é, produção de uma interpretação particular que apareceria, no entanto, como interpretação necessária e que atribui sentidos fixos às palavras, em um contex to histórico dado. (ORLANDI, 1996, p. 65)

Para realçar esse funcionamento, a autora propõe a noção de gesto de interpretação, que designa uma relação com o simbólico: "o gesto de interpretação é o

\footnotetext{
${ }^{3}$ Quanto à escrita deste texto, advertimos que está expressa numa versão um pouco nossa do português brasileiro "culto". Desse modo, pode não coincidir, em alguns pontos, com outras versões.
} 
que - perceptível ou não para o sujeito e/ou seus interlocutores - decide a direção dos sentidos, decidindo, assim, sobre sua (do sujeito) direção" (ORLANDI, 1996, p. 22) ${ }^{4}$.

Pensar teoricamente a interpretação, no entanto, não é apenas confirmar os sentidos formulados sob o efeito necessário da ideologia, mas compreender o movimento (simbólico) que torna possível certa interpretação em meio a outras (possíveis, prováveis).

Nesse sentido, o gesto de interpretação é, ao mesmo tempo, um efeito e um trabalho da relação do sujeito com os sentidos, com a memória, com a história, mas que, no discurso (formulação), aparece como um ato de um sujeito capaz de controlar os sentidos, inclusive seus efeitos sobre os interlocutores. Nisso está implicada a ilusão do controle argumentativo da linguagem pelo mecanismo de antecipação das formações imaginárias, que dá conta das relações entre as situações e lugares sociais e sua representação no discurso como posições (PÊCHEUX, 2010).

A argumentação, desse ponto de vista, não consiste num conjunto de estratégias textuais ou de procedimentos retóricos, mas num processo de ordem linguístico-histórica de constituição de sujeitos e de sentidos, que demarca trajetos e filiações em redes de memória:

se a argumentação é conduzida pelas intenções do sujeito, este tem no entanto sua posição já constituída e produz seus argumentos sob o efeito da sua ilusão subjetiva afetada pela vontade da verdade, pelas evidências do sentido. Os próprios argumentos são produtos dos discursos vigentes, historicamente determinados. Eles também derivam das relações entre discursos e têm um papel importante nas projeções imaginárias do nível da formulação, das antecipações. (ORLANDI, 1998, 78-79)

O processo argumentativo diz respeito, pois, aos movimentos de interpretação de que resultam os efeitos de sentido, quer na produção quer na leitura de textos. A esse propósito, podemos dizer que o gesto de interpretação, na produção textual, se desenvolve por um movimento que vai da dispersão real do (inter)discurso (a memória dos sentidos) para a unidade imaginária do texto (efeito-texto, efeito-autor, efeito-leitor); já no processo da leitura, o gesto de interpretação parte da unidade do texto para a dispersão do (inter)discurso.

No primeiro caso, se configura o movimento de textualização ou da "colocação do discurso em texto" (ORLANDI, 2005, p. 11), produzido sob os efeitos de autonomia imaginária do sujeito (efeito-autor) e da transparência dos sentidos (efeito-texto). No segundo, se pode observar o processo de discursivização no texto, isto é, o modo como os sentidos, "oriundos" do interdiscurso, estão nele se (re)apresentando e produzindo "seus" efeitos de sentido (efeitos-leitores). Nos dois casos, a interpretação está presente, pois, tanto num como noutro, isto é, na produção e na leitura, há movimento sobre o simbólico, "mexida na rede de filiação de sentidos", como diz Pêcheux (1990).

\footnotetext{
${ }^{4}$ A noção de "gesto" foi utilizada por Pêcheux (2010, p. 77) para se referir a um "sistema de signos não linguísticos", tais como aplausos, risos, assobio, "atos no nível do simbólico". Orlandi retoma e estende a noção ao discurso, o que permite aplicá-la a qualquer materialidade produtora de sentidos, e também aos domínios quer da leitura quer da produção de textos.
} 
A leitura, em especial, quando efetivada, produz um efeito-leitura, que é um novo efeito-texto. Esse efeito envolve a projeção de um efeito-leitor, ou seja, do lugar do outro/leitor como "unidade (imaginária) de um sentido lido" (ORLANDI, 2005, p. 65). No caso da produção, o efeito-leitor, projeção imaginária do sujeito-autor, é parte do mecanismo imaginário de controle da argumentação (a distribuição dos sentidos e das posições-sujeito no/do discurso).

No processo de leitura de um texto, portanto, a interação leitor/texto não se faz diretamente com o autor real, aquele que assina e se responsabiliza juridicamente pelo texto, mas com a função-autor e o efeito-leitor projetados no texto mediante gesto(s) de interpretação. Autor e leitor, no texto, são assim posições-sujeito, efeitos de sentidos, portanto, efeitos da relação do sujeito com as condições de produção do discurso. São essas posições e seus efeitos que demarcam as variadas leituras de um texto, que, em última instância, decorrem do fato de que a textualização e a discursivização se produzem com falhas. Se a ideologia, como diz Pêcheux (1997), é um ritual com falhas, o mesmo ocorre em relação à interpretação, o que significa dizer que há sempre possibilidade de deslize, de ressignificação nas/das práticas de linguagem e nas/das práticas sociais. Logo, há sempre possibilidade de interpretação.

O papel do leitor, nessa perspectiva, é interpretar o efeito-texto e seus efeitosleitores, produzindo novos-outros gestos de interpretação. Nesse processo, o leitor se constitui também como um sujeito-autor, pois ele reorganiza as posições e sentidos que atravessam e dão sustentação ao texto-lido, engendrando um "novo" efeito-texto, uma nova versão. Ao leitor analista de discurso, em especial, cabe entender o movimento da leitura do leitor ou como este produz seu gesto de interpretação.

O texto sobre o qual nos debruçaremos neste artigo, uma charge de humor político, será observado a partir dessa perspectiva teórica do discurso enquanto gesto de interpretação de um sujeito-autor que organiza imaginariamente sentidos e posições do (inter)discurso político produzindo certos efeitos de leitura. Portanto, vamos considerar o gesto de autoria/interpretação como estratégico e argumentativo, ainda que, em última instância, determinado por injunções ideológicas e inconscientes não totalmente controladas pelo sujeito.

\section{Condições de produção do texto analisado: dois atos falhos}

Nossa análise se concentrará sobre o funcionamento discursivo que sustenta a representação imaginária de sujeitos e sentidos na charge intitulada Ato falho, que foi veiculada no dia 09/07/2015, no site de humor charges.com.br, assinado por Maurício Ricardo e vinculado ao portal UOL.

O site, muito popular, produz "charges animadas", uma variedade do gênero que se utiliza de recursos de multimídia. Nesse sentido, representa uma inovação na linguagem das charges, tradicionalmente verbo-visuais e impressas. Reproduzimos, na Figura 1, imagem do quadro inicial da charge. ${ }^{5}$

\footnotetext{
${ }^{5}$ A versão completa da charge pode ser acessada em <http://charges.uol.com.br/2015/07/09/ato-falho/>.
} 
A charge em questão simula um diálogo entre Aécio Neves e Fernando Henrique Cardoso, sujeitos políticos brasileiros filiados ao PSDB (Partido da Social Democracia Brasileira), o primeiro, seu atual presidente; o segundo, seu Presidente de Honra. O contexto imediato do diálogo são os dois atos falhos cometidos por Aécio Neves em entrevistas concedidas a duas rádios, uma mineira e outra gaúcha, dias antes da publicação da charge.

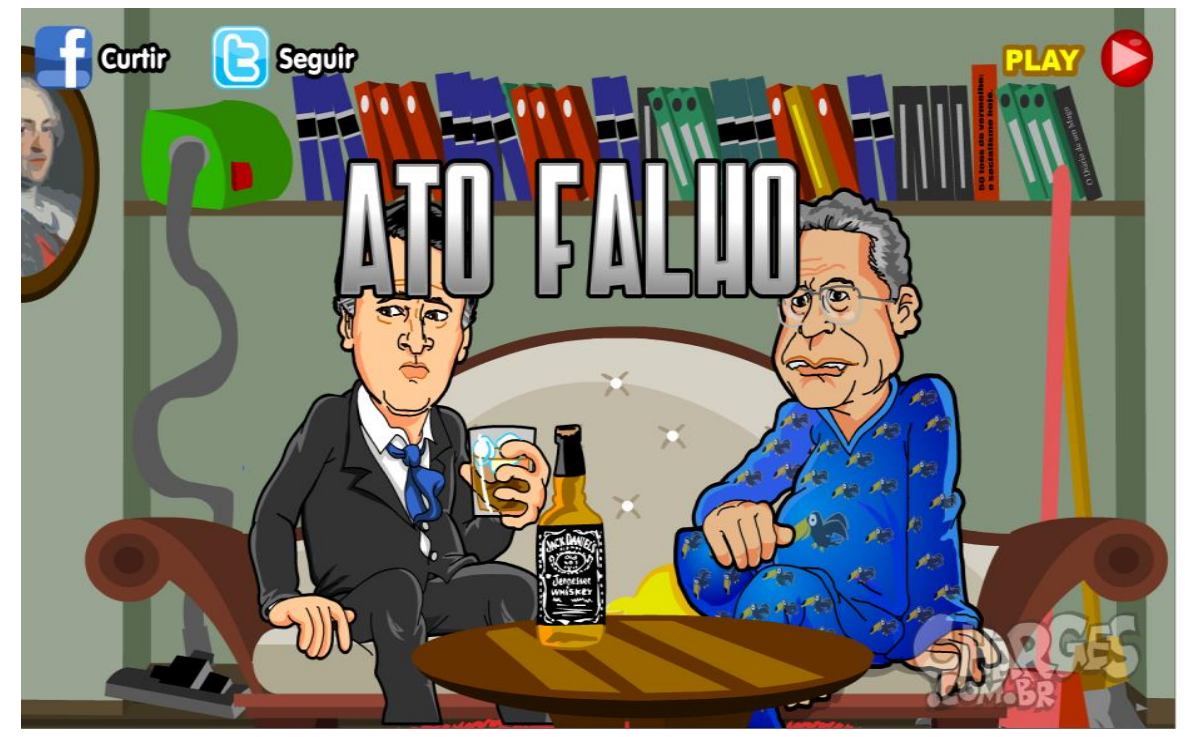

Figura 1. Imagem inicial da charge eletrônica Ato falho. Fonte: Charges.com.br.

De acordo com a matéria, os atos falhos do político tucano consistiram em duas afirmações: na primeira, Aécio teria dito que o PSDB é "o principal partido de oposição ao Brasil", em vez de "o principal partido de oposição do Brasil"; na segunda, teria afirmado ter sido eleito "presidente do Brasil", em lugar de "presidente do PSDB". Na Figura 2, podemos observar trecho de uma matéria sobre o fato, veiculada no portal Rede Brasil Atual. ${ }^{6}$

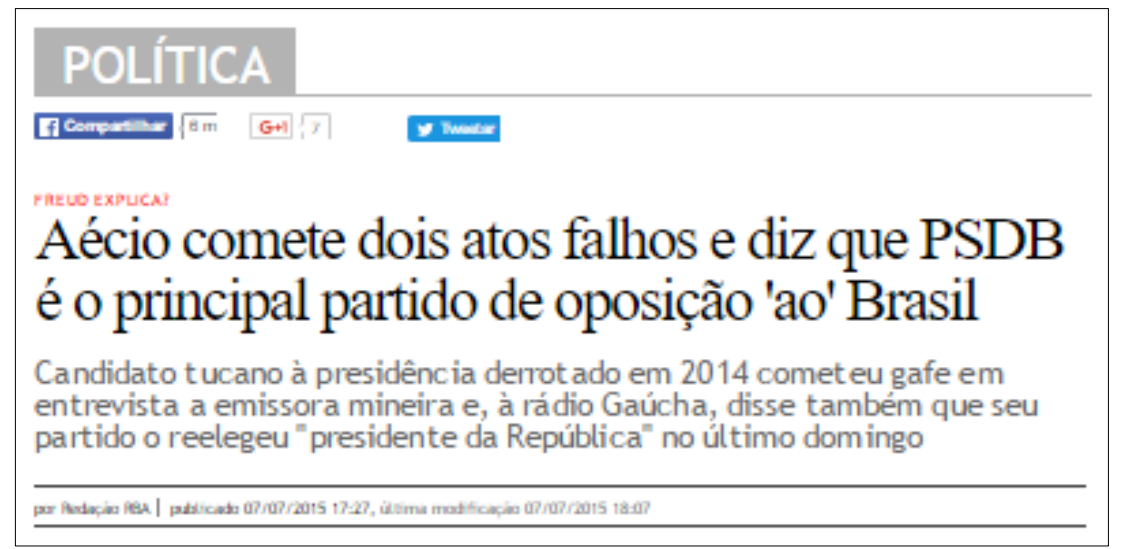

Figura 2. Chamada de notícia sobre atos falhos de Aécio Neves. Fonte: Portal Rede Brasil Atual.

\footnotetext{
${ }^{6}$ Ver matéria na íntegra em <http://www.redebrasilatual.com.br/politica/2015/07/aecio-comete-dois-atosfalhos-no-mesmo-dia-psdb-e-o-principal-partido-de-oposicao-ao-brasil-3431.html >.
} 
No corpo da matéria, há um detalhamento das entrevistas mencionadas e dos vários temas políticos nelas abordados, como a "disputa interna do PSDB pela candidatura à presidência da República em 2018" e a possibilidade de "fim antecipado do governo de Dilma Rousseff'. A matéria também registra o posicionamento de Aécio Neves sobre entrevista concedida pela Presidenta à Folha de São Paulo, na qual ela contesta "a intenção golpista de setores oposicionistas", afirmando ser esta intenção fruto de uma confusão entre "desejos" e "realidade".

Esses elementos da conjuntura política brasileira recente constituem as condições imediatas de produção do discurso da charge a ser analisada, que, através de uma recriação, expõe e interpreta sentidos da disputa política entre governo e oposição no período pós-eleição presidencial de 2014.

A charge de Maurício Ricardo simula um encontro privado entre Aécio Neves e Fernando Henrique Cardoso, Presidente de Honra do PSDB, ocorrido após as entrevistas concedidas pelo primeiro. Nesse encontro, os dois avaliam, em tom de cumplicidade, os atos falhos cometidos por Aécio, retomados e ampliados, na narrativa da charge, para produzir efeitos humorísticos e críticos.

O ato falho ou lapso de língua é, assim, o mecanismo central na construção do gesto de interpretação da charge aqui analisada sobre a política. Por isso, antes da análise propriamente dita do texto selecionado, faremos algumas observações sobre aquela noção, a fim de evidenciar sua importância heurística como indício de "algo relevante" na atividade dos sujeitos. Destacaremos, pois, a seguir, brevemente, a abordagem psicanalítica do ato falho inaugurada por Freud e uma possibilidade de sua abordagem discursiva.

\section{4. "Foi sem querer querendo"7: o que Freud explica sobre os atos falhos}

A expressão "ato falho" remete a um conceito elaborado por Freud (1976), em uma série de conferências introdutórias ao campo da Psicanálise proferidas entre 1915 e 1917. Para Freud, os atos falhos não são, como se costuma pensar, fenômenos triviais ou acidentais, mas "atos psíquicos" dotados de significação própria ("sentido", "propósito", "intenção") e de grande relevância para a compreensão da atividade mental dos indivíduos.

Tratando mais especificamente dos "lapsos de língua", Freud observa que esse tipo de "parapraxia" (designação dos atos falhos de modo geral) ocorre quando uma pessoa tenciona dizer uma coisa e diz outra, engendrando um conflito entre duas "tendências", uma "interferência mútua" entre duas "elocuções desejadas". Uma dessas elocuções é designada "intenção perturbada"; a outra, "intenção perturbadora". Nos lapsos, essas duas intenções não são igualmente conscientes, manifestas ou reconhecidas pelo sujeito que produz a ato falho, se estabelecendo entre elas relações de substituição, distorção ou modificação.

\footnotetext{
${ }^{7}$ Expressão usada pelo personagem Chaves, do conhecido seriado de humor mexicano, quando cometia alguma ação desastrada.
} 
Assim, nos lapsos de língua, a relação entre as elocuções implicadas pode se configurar, dentre outros casos, como: a) substituição de uma elocução pelo seu sentido contrário; b) contraste de sentidos entre elocuções; c) produção de um sentido outro por condensação ou abreviação de elocuções diversas.

Os atos falhos que deram origem à charge que vamos analisar se enquadram na categoria dos lapsos por contraste de sentidos, conforme se pode visualizar a seguir:

O PSDB é o principal partido de oposição ao Brasil. (Elocução perturbadora)

O PSDB é o principal partido de oposição do Brasil. (Elocução perturbada)

Fui eleito presidente do Brasil. (Elocução perturbadora)

Fui eleito presidente do PSDB. (Elocução perturbada)

No primeiro caso, há um contraste quanto ao escopo da palavra "oposição" (ao Brasil/do Brasil). Aqui a elocução perturbadora, a que materializa o lapso, sugere um sentido não admitido, não reconhecido a respeito do tipo de oposição feita pelo PSBD na conjuntura considerada: uma oposição que não levaria em conta os interesses do país, mas do próprio partido. No segundo caso, o contraste diz respeito ao escopo da palavra "presidente" (do Brasil/do PSDB), remetendo a elocução perturbadora ao desejo reprimido, mas não abandonado, do sujeito Aécio Neves de ser presidente do Brasil e não apenas de seu partido.

A interpretação dos efeitos de um lapso, vale destacar, não é subjetiva; decorre da consideração do sujeito que o produz, das circunstâncias de sua produção e também dos eventos subsequentes a ela. São funcionamentos que, segundo Freud (1976, p. 97), fazem da vida mental "a arena e o campo de batalha de intenções que se opõem reciprocamente".

Os lapsos são ainda "estruturas compostas", em geral dúplices, que apontam para intenções conflitantes, sendo uma de suas partes manifesta, enquanto a outra necessita ser explicitada ou descoberta. Aqui se coloca a questão da identificação e validação das "intenções" de um lapso. Quanto a isso, Freud explica que a intenção perturbada, embora não manifesta, é geralmente admitida e reconhecida pelo sujeito que comete o lapso; quando isso não acontece, a intenção perturbada (o "suspeito sentido") pode ser desvelada pela técnica psicanalítica (exame do "ato psíquico").

Há diferentes modos de funcionamento das "intenções" de um lapso em relação aos sujeitos: o sujeito pode reconhecer a intenção perturbadora e a inconveniência dela; pode reconhecer ela, mas com um sentimento de "surpresa"; ou, por fim, rejeitá-la, negando sua atuação nele. No terceiro grupo, há uma diferença de grau na rejeição da intenção perturbadora, uma vez que essa é repelida, mesmo sem ser percebida. Nos três casos, porém, o lapso sempre acontece:

[...] a intenção, que foi repelida, é expressa em palavras, contra a vontade de quem fala, seja alterando a expressão da intenção permitida, seja confundindo-se com essa expressão, ou realmente tomando seu lugar. (FREUD, 1976, p. 84-85)

Por isso é que os lapsos são definidos também como uma espécie de "acordo", "um meio-êxito e um meio-fracasso" para cada uma das intenções embaralhadas, pois "a 
intenção que está sendo desafiada não é completamente suprimida, salvo em casos especiais, nem é levada a cabo em sua íntegra" (FREUD, 1976, p. 86). Esse "mecanismo" ambivalente dos lapsos de língua é, então, o vestígio da própria "dinâmica dos fenômenos mentais", objeto da psicologia freudiana.

Ainda segundo Freud, uma prova de que os lapsos de língua são uma realidade psíquica é sua utilização intencional pelos escritores na produção de "efeitos de imaginação", pois isto só é possível na pressuposição de que tais fenômenos tenham, de fato, sentido próprio.

A charge escolhida para análise neste trabalho ilustra bem a dupla realização do ato falho (como ato psíquico "espontâneo" e como fato estilístico intencional), pois trata de uma ocorrência real de atos falhos que foi explorada e ampliada para produzir efeitos de humor e de crítica política.

Considerados de um ponto de vista discursivo, podemos afirmar que os atos falhos, ao trazerem à tona sentidos indesejados, recalcados, que não podem/devem ser ditos, funcionam sob a forma de enunciados divididos (COURTINE, 1999), enunciados em relação de antagonismo que expõem uma divisão contraditória dos sujeitos e dos sentidos.

Os atos falhos podem também ser pensados em relação à noção de formação discursiva (FD), definida por Pêcheux (1997, p. 160; grifos do autor) como "aquilo que, numa formação ideológica dada, isto é, a partir de uma posição dada numa conjuntura dada, determinada pelo estado da luta de classes, determina o que pode e deve ser dito".

Quanto a isso, podemos levantar a hipótese de que o ato falho representa uma ruptura não consciente ou pré-consciente com os elementos da FD na qual o sujeito habitualmente se inscreve, o que o obriga a negá-la no nível do intradiscurso. $\mathrm{O}$ ato falho, desse modo, faz com que um não-dito se confronte com (e afronte) o que poderia/deveria ser dito a partir da rede de memória com a qual o sujeito se identifica.

Considerando assim os pressupostos acima apresentados, passamos à análise discursiva da charge de humor político.

\section{Charge, ato falho e movimentos de sentido}

Na situação enunciativa representada na charge Ato falho, conforme mencionado na seção 4, há uma simulação de continuidade dos acontecimentos políticos que envolvem os atos falhos cometidos pelo sujeito político Aécio Neves.

$\mathrm{Na}$ imagem inicial da charge (voltar à Figura 1), Aécio Neves (AN) e Fernando Henrique Cardoso (FHC) estão no que parece ser a casa deste último. AN está de terno, porém com a gravata desfeita e a camisa desabotoada, tomando uma dose de uísque. FHC aparece em um pijama com estampas do tucano símbolo do PSDB. Os dois estão sentados numa poltrona semelhante a um divã, elemento que remete a uma situação de tratamento psíquico, o que quebra o clima de descontração. AN tem uma expressão facial um tanto 
contrariada (sobrancelhas juntas, boca fechada e levemente caída, olhar oblíquo), enquanto FHC aparenta um ar reflexivo, meio distante. Atrás dos personagens, há uma estante de livros, referência ao perfil intelectual de FHC, o "presidente sociólogo". Dois dos livros trazem títulos expressos - 50 tons de vermelho: o socialismo hoje e Diário de um mago -, o primeiro, um trocadilho com o livro 50 tons de cinza, um best-seller romântico-erótico; o segundo, o conhecido best-seller do escritor Paulo Coelho. Essas referências remetem ao perfil político de FHC, a suas posições políticas cambiantes de/sobre a esquerda e ao seu papel de "conselheiro" político.

Ao longo da animação, AN e FHC discutem os atos falhos cometidos pelo primeiro, mote utilizado pelo chargista para produzir seu gesto de interpretação sobre a conjuntura sócio-política do momento, em particular sobre o posicionamento do PSDB quanto ao resultado da eleição presidencial e a "sucessão" da candidata do PT na presidência da República. Com esse gesto, o sujeito-autor da charge retoma e faz trabalhar discursivamente sentidos e saberes (pré-construídos) da memória política brasileira recente.

$\mathrm{Na}$ textualização desses sentidos e saberes, o chargista não somente se apropria dos atos falhos efetivamente cometidos por AN como também imagina outros, explorando assim os efeitos desse mecanismo psíquico e discursivo, que é um sintoma do funcionamento equívoco da língua.

Esse funcionamento, de acordo com Pêcheux e Gadet (2011, p. 103), sustenta a possibilidade da interpretação como um "jogo com as regras", em vez de uma simples e redutora obrigação de "seguir as regras de um jogo". É principalmente a partir dessa possibilidade de "jogo com as regras" que são produzidos os efeitos de sentido na charge Ato falho. E é também por meio da observação desse jogo que podemos compreender como se produz nela o movimento de significação que define o gesto de interpretação do chargista.

A fim de demonstrar esse processo, analisamos, a seguir, o diálogo verbal que constitui o texto da charge selecionada. Para tanto, transcrevemos inicialmente esse diálogo, dividido em sequências discursivas ${ }^{8}$ (SD), nas quais destacamos, em negrito, os fragmentos que remetem aos atos falhos relatados e "imaginados" pelo chargista.

\section{SD1}

FHC: Nós somos o maior partido de oposição ao Brasil...

AN: Quis dizer “do Brasil”! Ato falho, Fernando! Ato falho!

\section{SD2}

FHC: Você foi reeleito "presidente da República"?

AN: Não, "presidente do PSDB"! Também foi ato falho!

FHC: Duas entrevistas! Duas cagadas! Ato falho, Aecinho, foi o nosso ao te escolher como candidato à presidência!

\section{SD3}

AN: Como assim? Vocês estão pensando em outro nome para quando a Dilma cair? FHC: Dilma o quê?

\footnotetext{
${ }^{8}$ Por sequência discursiva se entende um fragmento ou porção de texto referido a uma situação discursiva (ORLANDI, 2001).
} 
AN: Sair! Ato falho! Mas ela vai...

FHC: PSSST! Não pronuncie em voz alta! O que a gente combinou que iria dizer?

AN: Que a gente não quer ver o Estado direito, quer golpe! Digo, que quer ver o Estado de direito, não golpe!

FHC: Aí... Ansioso demais... Despreparado demais...

AN: Ato falho!...

\section{SD4}

FHC: Entenda, temos nos quadros do partido outros...

AN: Não, Fernando! O Alckmin e o Serra de novo não! Me deem outra chance! Eu consigo derrubar a Dilma!

FHC: Consegue o quê?

AN: Derrotar a Dilma!

FHC: Ó, de novo!

\section{SD5}

AN: Eu tô estressado, sem dormir direito... Vocês estão querendo me queimar por quê?

FHC: Pra mostrar que aceitamos o resultado das urnas! Você perdeu! Se voltarmos ao poder, será no tapetão!

AN: Será o quê?

FHC: Na eleição!

AN: Você disse: "no tapetão"!

FHC: Não, eu disse: "na eleição"!

AN: "Tapetão", eu não sou surdo!

FHC: Pode não ser, mas não me ouviu direito! Eu disse: "na eleição"!

AN: Você disse; "no tapetão"!

$[\ldots]$

As sequências discursivas 1 e 2 são reapresentações dos atos falhos efetivamente cometidos por AN e dizem respeito aos temas do papel político do PSDB como partido de oposição (SD1) e de Aécio Neves como líder do partido (SD2). Nas sequências de 3 a 5 , os atos falhos foram criados pelo chargista a partir de elementos do contexto político em que os dois primeiros foram produzidos.

Em SD1, os termos "partido" e "oposição" são elementos pré-construídos que inscrevem o texto no campo da política, cuja disputa, nos países democráticos, se desenrola pela divisão dos "partidos políticos" em grupos antagônicos, dos quais uns se definem como "oposição" (os que não ocupam o governo), enquanto outros, como "situação" (os que ocupam o governo).

No contexto da charge e dos acontecimentos políticos a que se refere, a retomada desses pré-construídos se dá em relação à conjuntura particular da disputa política entre o governo petista de Dilma Rousseff e seu principal partido de oposição, o PSDB.

Na formação imaginária da disputa política democrática, os sentidos relativos às posições de "oposição" e de "situação" (ou "governo") são legitimados por uma memória ligada a regras segundo as quais os partidos podem e devem disputar o melhor projeto para a gestão do País. Entretanto, na formulação de sua posição oposicionista, AN comete um ato falho que desloca e desorganiza os sentidos da formação imaginária política referida, produzindo efeitos de sentido não previstos, não esperados, cujo vestígio textual é a expressão "oposição ao Brasil" dita em lugar de "oposição ao governo". 
Na primeira expressão, do ponto de vista linguístico, os termos estão devidamente articulados pelo processo de subordinação sintática (uma estrutura completiva nominal); entretanto, nas condições linguístico-históricas em que foram produzidos, remetem a sentidos incompatíveis, sinalizando assim deslocamentos de posições e sentidos. O enunciado "Nós somos o maior partido de oposição ao Brasil", que assinala o ato falho em SD1, desloca os sentidos legitimados da posição oposicionista ("Nós somos o maior partido de oposição do Brasil") para um outro lugar de significação: do sentido de oposição entre grupos ou partidos políticos para um estranho sentido de oposição entre partido ou grupo político e país.

Esse deslocamento de sentido e de posições está, portanto, em contradição com as formulações possíveis da rede de memória política democrática, pois, no discurso político que se pretende democrático, são aceitáveis enunciados que falem de "oposição ao governo", mas não aqueles que signifiquem "oposição ao país". Entretanto, como as formações imaginárias são ideológicas e não há ideologia sem falhas, ocorrem os atos falhos, que embaralham essas posições e sentidos, assinalando contradições éticas da política e de seus sujeitos.

A SD2 se refere ao segundo ato falho cometido por AN, que diz respeito ao lugar político que acabava de ocupar na ocasião. Nessa sequência, a palavra "presidente" é um lugar de equívoco, uma vez que foi usada em referência a lugares sociais e discursivos que não podem ser preenchidos pelo mesmo sujeito: "presidente de país" e "presidente de partido". No caso específico representado nessa sequência, o efeito do ato falho ocorre pelo desencontro factual entre o sujeito que se coloca na posição de "presidente do Brasil", AN, e aquela que foi efetivamente eleita para o cargo, Dilma Rousseff. O lapso aqui entra em choque com as formulações possíveis da rede de memória política recente do Brasil, especificamente aquelas relativas às eleições e seus resultados.

Os atos falhos referidos nas $\mathrm{SD} 1$ e $\mathrm{SD} 2$, proferidos por $\mathrm{AN}$ e reutilizados na charge sob análise, se constituem, pois, "enunciados divididos", em relação de paráfrase e antagonismo ("Maior partido de oposição do [ao] Brasil" e "Presidente do PSDB [do Brasil]"), que tornam ambígua a posição do PSDB e de seu então ex-candidato à Presidência da República, então, atual presidente do partido. Os deslizamentos metafóricos implicados nos atos falhos de AN, portanto, expõem ao tensionamento as fronteiras da FD peessedebista e sua identidade histórica de partido socialdemocrata, na medida em que coloca em dúvida a aderência a uma posição oposicionista dentro das regras democráticas.

Os efeitos de sentido das paráfrases que constituem os enunciados divididos de SD1 e SD2, vale destacar, não são o resultado de propriedades sintáticas da língua, mas de processos discursivos ligados à memória dos sentidos. A interpretação, nesse caso, não se define tendo em vista supostos conteúdos gramaticais de elementos da língua ou por uma mudança sintática de termos ou funções (por exemplo, no primeiro enunciado, a alternância de uma estrutura adjuntiva nominal (do Brasil) por uma completiva nominal (ao Brasil). Se trata aqui de paráfrase histórica, ou seja, de uma articulação com filiações específicas no interdiscurso político, evidenciando a ligação entre língua e história.

Por outro lado, não estamos falando de "alternância" de interpretações, mas de relação constitutiva entre língua e história. Ou seja: nas paráfrases discursivas, o 
deslizamento de uma formulação a outra é parte da significação. Aliás, é a significação, o efeito de sentido. No caso particular sob análise, as paráfrases remetem a efeitos de sentido ligados à posição política ambígua do PSDB, na conjuntura dada, e não a um deslocamento definitivo de uma posição a outra.

Na SD3, o sujeito-autor da charge, valendo-se do funcionamento equívoco da língua, da possibilidade de jogo com suas regras, replica os efeitos metafóricos das formulações divididas de SD1 e SD2, amplificando a leitura dos efeitos de sentido dos atos falhos de AN. Para isso, explora a relação parafrástica sinonímica implicada em duas séries de formulações "Quando a Dilma sair"/“Quando a Dilma cair" (sintetizadas no enunciado "Quando a Dilma cair [cair] sair") e "a gente não quer ver o Estado direito, quer golpe"/“(a gente) quer ver o Estado de direito, não golpe" (sintetizável em "a gente [não] quer ver o Estado /de/ direito, [não] quer golpe").

A série de formulações de SD3 inscreve o discurso da charge na memória das formas de ocupação e de alternância do poder político: pela via democrática, dentro dos limites da legalidade, ou pela ruptura das instituições democráticas. Essas posições são sinalizadas, na primeira série, pela oposição lexical entre os verbos "sair" e "cair", que remetem a formações e posições discursivas antagônicas; na segunda série, os mesmos efeitos de sentido são reiterados pelo contraste de estruturas negativas e afirmativas, trocadilhos e antíteses lexicais: "Não quer ver o Estado direito"/"Que ver o Estado de direito", "Estado (de) direito"/ "golpe".

Esses enunciados, pertencentes a redes de filiação distintas, mas colocados na fala de um mesmo personagem, produzem um efeito de contradição relacionado à identidade política do PSDB, insinuando um "flerte" com tendências políticas que, na ocasião, faziam circular, em protestos e nas redes sociais, sentidos antidemocráticos ${ }^{9}$, sentidos esses oriundos da memória política brasileira, quer recente (memória dos protestos contra o governo Dilma em 2013, por exemplo), quer mais distante no tempo (memória da última ditadura militar no Brasil).

Ainda na SD3, podemos destacar o trecho em que o personagem FHC faz uma admoestação ao personagem AN sobre seu descontrole verbal: "PSSST! Não pronuncie em voz alta! O que a gente combinou que iria dizer?". Essa formulação, embora pareça uma impostura do chargista, produzida para comprometer a reputação do sujeito político FHC, representado na charge, na verdade, se sustenta também na memória das práticas políticas, que se caracteriza por uma divisão contraditória entre dizer (o que se pode/deve dizer) e não dizer (o que não se pode/deve dizer), tendo em vista a possibilidade de obter a aprovação e legitimação popular. A formulação colocada na voz de FHC expõe essa divisão do discurso político, assinalando, em particular, a discrepância ética entre as estratégias públicas e privadas de disputa pelo poder.

As formulações destacadas na SD4 (“...derrubar a Dilma” e "derrotar a Dilma”) se inscrevem na mesma série parafrástica de SD3, remetendo, pois, ao já mencionado confronto de formas políticas de ocupação do poder: pela via democrática (derrotar eleitoralmente) e pela via golpista (derrubar pela ruptura institucional). $\mathrm{O}$ antagonismo dessas duas posições é marcado no trecho pela antítese verbal "derrubar"/ "derrotar".

\footnotetext{
${ }^{9}$ Estamos nos referindo aqui, por exemplo, a manifestações, largamente registradas pela mídia, pedindo a
} volta da ditadura militar. 
As formulações da SD5, uma série discursivamente antonímica ("no tapetão"/"na eleição") também remetem a sentidos antagônicos. Entretanto, o antagonismo agora se refere à oposição entre formas de alternância do poder pelo sufrágio eleitoral ("na eleição") e por via jurídica ("no tapetão"), já que a expressão futebolística "no tapetão" se refere aos resultados de jogos de futebol contestados e decididos fora do campo.

Essa expressão futebolística, na charge, é transferida para o discurso políticoeleitoral, fazendo referência à memória das tentativas de alteração do resultado da eleição de 2014 por parte do PSDB, que, logo após o segundo turno, contestou na Justiça Eleitoral o resultado do pleito, alegando, segundo matéria jornalística da época, "descrença quanto à confiabilidade da apuração dos votos e à infalibilidade da urna eletrônica"10.

$\mathrm{Na}$ criação do chargista, o ato falho dessa sequência ("no tapetão" por "na eleição") é colocado na boca de FHC, e não mais de AN. Isso resulta num efeito de sentido de que os "atos falhos" de AN expressariam também a posição do presidente de honra do partido, pondo sob suspeição todo o partido. Essa leitura contesta a ideia de que o deslizamento político conservador e antidemocrático vislumbrado no discurso de AN seria resultado exclusivamente de seu desejo pessoal de ocupar o poder, mas algo referendado por outras lideranças do partido. A charge é concluída, no entanto, com um "disse-que-disse" entre AN e FHC sobre o ato falho a respeito da forma de sucessão da Presidenta Dilma, apontando assim para um tensionamento interno de posições no discurso do PSDB.

\section{A charge e seu funcionamento argumentativo e político}

Considerando, portanto, o gesto de interpretação do sujeito-autor chargista, podemos observar como são reconstruídas, enquanto efeito de leitura, as posições dos sujeitos políticos AN e FHC. Inicialmente essas posições são apresentadas como antagônicas, uma vez que os "atos falhos" cometidos pelo primeiro sujeito inscrevem a posição pessedebista (tucana) num domínio de memória em contradição com sua posição de partido liberal, de centro-esquerda, defensor dos valores democráticos e republicanos. AN, assim, é representado num jogo contraditório entre a necessidade do dizer político (ser democrático) e a subjetividade do querer individual (ser presidente do Brasil); FHC, por sua vez, encarna a representação dos valores éticos e políticos da democracia e do republicanismo, censurando os "atos falhos" de AN, que o desqualificariam a uma segunda candidatura pelo PSDB à sucessão de Dilma. Ao final da charge, no entanto, o sujeito-autor faz crer que o personagem FHC, que também comete um ato falho, não é tão convicto dos valores democráticos, colocando sob suspeita a memória política do PSDB, que ele representa.

O gesto de leitura do chargista expõe, portanto, um movimento contraditório no discurso desses sujeitos políticos, que remete a domínios de saberes antagônicos da história política brasileira. Com isso, o efeito-leitura dessa charge, no âmbito político e ideológico, problematiza o pretenso deslizamento da posição política do PSDB do centro

10 Ver matéria sobre isso em <http://politica.estadao.com.br/noticias/geral,psdb-de-aecio-neves-pedeauditoria-na-votacao, $1585755>$. 
para a direita do espectro político e de uma posição de defesa do Estado democrático de direito para o consentimento com o Estado de exceção.

Por essa interpretação, a disputa política entre PSBD e PT não se apresentaria, na atual conjuntura, como um embate dentro de uma mesma formação discursiva política (uma FD democrática), mas entre duas FDs distintas: uma FD democrática e uma FD antidemocrática, já que, na primeira, o embate político é regido por uma disputa entre posições governistas e oposicionistas, sem ruptura do Estado democrático de direito, enquanto na segunda, a posição oposicionista se reveste de um sentido golpista, tensionando/pressionando a estabilidade da FD democrática, a fim de impor uma outra forma de hegemonia política. Neste caso, a disputa entre "amigos e inimigos" no campo político (CORTEN, 1999) seria feita num jogo segundo regras diferentes. A posição crítica da charge sugere, portanto, que a ação política dos representantes do PSDB estaria sendo feita, ainda que dissimuladamente, fora das regras do jogo democrático, desenhando para o PSDB um novo trajeto de sentidos.

\section{Considerações finais}

O funcionamento estratégico e argumentativo resulta de processos históricodiscursivos que sustentam todo dizer, legitimando posições, filiações e trajetos específicos para sujeitos e sentidos.

No caso da charge analisada, pudemos observar que as posições discursivas ou imagens construídas para os sujeitos políticos AN e FHC e para os objetos de seus discursos - as demandas do jogo político atual - não são meramente fruto da imaginação do sujeito-autor, mas uma forma de relação e trabalho com/sobre os saberes da memória política brasileira, retomados, deslocados, intensificados etc. Nessa movimentação, no caso do discurso humorístico, a unidade contraditória do discurso político é exposta, remexida, deixando entrever compromissos históricos e políticos, suas direções de sentido, suas "ideologias", nem sempre visíveis a olho nu ou na telinha da TV.

É a partir dessa inscrição na historicidade que o sujeito-autor da charge produz seu gesto crítico de interpretação, inserindo-se também na ordem do político, na ordem da persuasão e da circulação de versões (CORTEN, 1999), expondo-se também à leitura. Ser um sujeito crítico, fazer interpretações críticas, assim, supõe a imersão na historicidade das coisas, do mundo, dos discursos; reconhecer, articular, jogar com as posições e filiações, produzindo versões, entrando no jogo dos discursos e de seus efeitos, para reiterá-los ou contestá-los.

Sobre o discurso de humor político, considerando que este não tem sua origem a origem de seus efeitos - numa propriedade particular da linguagem, caberia indagar ainda, por que rimos e sentimos prazer em face de coisas tão sérias, como a dissimulação política? De que rimos de fato?

Retomando a observação de Freud (1974), de que o humor "tem algo de grandeza e elevação", por insistir em prevenir os indivíduos de serem afetados pelos "traumas do mundo externo", diríamos que o prazer do humor, principalmente o político, está em não 
permitir o enclausuramento dos sujeitos nos efeitos de evidência do discurso e das práticas dos políticos, que querem sempre transformar leitores em meros eleitores.

\section{Referências bibliográficas}

CORTEN, A. Discurso e representação do político. Em: INDURSKY, F; FERREIRA, M.C.L. (Orgs). Os múltiplos territórios da Análise do Discurso. Porto Alegre: Editora Sagra Luzzatto, 1999. pp. 37-52.

COURTINE, J. O chapéu de Clémentis. Em: INDURSKY, F; FERREIRA, M.C.L. (Orgs). Os múltiplos territórios da Análise do Discurso. Porto Alegre: Editora Sagra Luzzatto, 1999. pp. 15-22.

DICIONÁRIO ELETRÔNICO HOUAISS DA LÍNGUA PORTUGUESA. Rio de Janeiro: Objetiva, 2009.

FREUD, S. O humor. Edição Standard Brasileira das Obras Psicológicas Completas de Sigmund Freud: Volume XXI. Rio de Janeiro: Imago, 1974.

Conferências introdutórias sobre psicanálise (Partes I e II) (1915-1916). Edição Standard Brasileira das Obras Psicológicas Completas de Sigmund Freud: Volume XV. Rio de Janeiro: Imago, 1976.

ORLANDI, E.P. Discurso e texto: formulação e circulação dos sentidos. $2^{a}$. ed. São Paulo: Pontes, 2005.

As formas do silêncio: no movimento dos sentidos. $5^{\text {a }}$. ed. Campinas, SP: Editora da UNICAMP, 2002.

Análise de discurso: princípios e procedimentos. 2a . ed. São Paulo: Pontes, 2001.

Discurso e argumentação: um observatório do político. Fórum Linguístico, PPG em Linguística da UFSC, Florianópolis, n. 1, julho a dezembro de 1998. p. 73- 81. Disponível em <https://periodicos.ufsc.br/index.php/forum/article/view/6915>; acesso em 12/05/2016.

Vozes, 1996.

Interpretação: autoria, leitura e efeitos do trabalho simbólico. $2^{\mathrm{a}}$. ed. Petrópolis:

PÊCHEUX, M. Análise automática do discurso (AAD-69). Em: GADET, F.; HAK, T. (Orgs.). Por uma análise automática do discurso. $4^{\mathrm{a}}$. ed. Campinas-SP: Editora da UNICAMP, 2010. pp. 59-158.

Semântica e discurso: uma crítica à afirmação do óbvio. $3^{a}$. ed. Campinas-SP: Editora da UNICAMP, 1997.

O discurso: estrutura ou acontecimento. Campinas-SP: Pontes, 1990. 
PÊCHEUX, M.; FUCHS, C.A propósito da análise automática do discurso: atualização e perspectivas (1975). Em: GADET, F.; HAK, T. (Orgs.). Por uma análise automática do discurso. $4^{\text {a }}$. ed. Campinas, SP: Editora da UNICAMP, 2010. pp. 159-249.

PÊCHEUX, M.; GADET, F. A língua inatingível. Em: PÊCHEUX, M. Análise de discurso: Michel Pêcheux. Textos selecionados por Eni P. Orlandi. Campinas: Editora da UNICAMP, 2011. pp. 93-105.

POSSENTI, S. Os humores da língua: análises linguísticas de piadas. $3^{\text {a }}$. reimp. Campinas, SP: Mercado de Letras, 2002.

Artigo recebido em: junho de 2016.

Aprovado e revisado em: julho de 2016.

Publicado em: agosto de 2016

\section{Para citar este texto:}

FARIAS, Washington Silva de; SILVA, Telma Cristina Gomes da. O gesto de interpretação no discurso de humor político: o caso de uma charge. Entremeios [Revista de Estudos do Discurso], Seção Estudos, Programa de Pós-graduação em Ciências da Linguagem (PPGCL), Universidade do Vale do Sapucaí, Pouso Alegre (MG), vol. 13, p. 151-167, jul. - dez. 2016.

DOI: http://dx.doi.org/10.20337/ISSN2179-3514revistaENTREMEIOSvol13pagina151a167 